\title{
Keanekaragaman Plankton Di Kolam Pertumbuhan Ikan Bandeng (Chanos chanos Forsskal) yang Terparasiti di Desa Balongpanggang Gresik
}

\section{Diversity of Plankton in the Growth Pond of Parasitized Milkfish (Chanos chanos Forsskal) in Balongpanggang Village, Gresik}

\author{
Rizki Kusuma Hantika ${ }^{1 *}$, Ratna Djuniwati Lisminingsih ${ }^{2}$, Nour Athiroh $\mathrm{AS}^{3 * *}$ ) \\ ${ }^{123}$ Jurusan Biologi Fakultas Matematika dan Ilmu Pengetahuan Alam Universitas Islam Malang, Indonesia
}

\begin{abstract}
ABSTRAK
Peranan plankton dalam ekologi sebagai parameter subur tidaknya perairan, karena plankton merupakan dasar mata rantai pakan alami di perairan Penelitian terdahulu dilakukan pada morfologi dan anatomi ikan Bandeng (Chanos chanos Forsskal) dalam suatu tambak di desa Balongpanggang, Gresik yang perairannya tercemar. Ditemukan cacing parasit nematoda dalam usus ikan yang berimbas pada kerugian bagi petani ikan. Tujuan dari penelitian ini yaitu untuk mengidentifikasi, mengetahui perbedaan, tingkat kenekargaman jenis plankton dan kondisi faktor abiotik kolam. Penelitian menggunakan 24 sampel dari 3 kolam yang terparasiti dan 1 kolam yang tidak terparasiti dengan metode Rancangan Acak Kelompok (RAK). Berdasarkan hasil pengamatan dan identifikasi plankton pada Kolam Pertumbuhan Ikan Bandeng yang Terparasiti didapatkan spesies Chlorococcum humicola sebanyak 53 sel dan spesies Stentor roeseli sebanyak 37 individu. Ditemukan Fitoplankton yang keberadaannya ada di semua kolam, yaitu Chlorella variegatus, Chlorococcum humicola, Navicula cuspidata, Navicula placentula, Nostoc sphaericum, dan Protococcus viridis. Sedangkan Zooplankton hanya 1 disemua kolam, yaitu Stentor roeseli. Kolam tidak terparasiti merupakan kolam yang memiliki nilai tingkat keanekaragaman plankton tertinggi $(5,7)$, daripada kolam terparasiti $2(5,0)$. Kondisi faktor abiotik $(\mathrm{pH})$ pada semua kolam masih sesuai standar kualitas air untuk budidaya tambak.
\end{abstract}

Kata kunci: Plankton, Identifikasi, Indeks Keanekaragaman

\section{ABSTRACT}

The role of plankton in ecology as a parameter of lush or not a waters, because plankton is the basis of the natural feed chain in the waters. The previous research has been done on the morphology and anatomy of milkfish (Chanos chanos Forsskal) at the pond in the village of Balongpanggang, Gresik, where the waters are polluted. Parasitic worms found nematodes in fish intestines have an impact on losses for fish farmers. The purpose of this study is to identify, find out the differences, determine the level of risk of the type of plankton and determine the condition of abiotic factors in the pond. The study used 24 samples from 3 parasites and 1 non-parasite pond using the Randomized Block Design (RBD) method. Based on the results of observations and identification of plankton in the Integrated Milkfish Growth Pool, there were 53 cells of Chlorococcum humicola and 37 individuals of Stentor roeseli. Phytoplankton found in all ponds, namely Chlorella variegatus, Chlorococcum humicola, Navicula cuspidata, Navicula placentula, Nostoc sphaericum, and Protococcus viridis. While Zooplankton is only 1 in all pools, namely Stentor roeseli. Unparasitic ponds have the highest plankton diversity level (5.7), rather than parasitic ponds 2 (5.0). The condition of abiotic factors ( $p H$ ) in all ponds is still in accordance with water quality standards for aquaculture ponds.

Keywords: Plankton, Identification, Diversity level

\footnotetext{
*) Rizki Kusuma Hantika, Jurusan Biologi FMIPA UNISMA, Jl. MT Haryono 193, Malang 65144 Telp. 087759252050 Email: hankusuma82@gmail.com

${ }^{* *}$ Dr. Ratna Djuniwati L., M.Si, Jurusan Biologi FMIPA Universitas Islam Malang, Jl. M.T Haryono 193, Malang 65144, 083852023027 and e-mail: ratnadj_uniwati@yahoo.com
}

Diterima Tanggal 12 Juli 2019 - Dipublikasikan Tanggal 25 Agustus 2020 


\section{Pendahuluan}

Plankton merupakan organisme yang berukuran sangat kecil atau biasa disebut jasad renik yang hidup melayang dalam air. Plankton terbagi menjadi 2 golongan yaitu plankton yang bersifat tumbuhan yang disebut fitoplankton dan plankton yang bersifat hewan disebut zooplankton [1]. Keberadaan organisme plankton di perairan dipengaruhi oleh beberapa faktor lingkungan dan karakteristik fisiologisnya. Komposisi dan kelimpahan plankton dapat berubah di berbagai tingkatan sebagai respon terhadap perubahan kondisi lingkungan baik fisika, kimia, maupun biologi [2].

Berdasarkan hasil penelitian yang telah dilakukan pada morfologi dan anatomi ikan Bandeng (Chanos chanos Forsskal) oleh Rohman [3] bahwa terdapat suatu tambak ikan Bandeng di desa Balongpanggang, Gresik yang diduga perairannya telah tercemar, ditemukan cacing parasit Nematoda dalam usus ikan Bandeng tersebut. Hal ini menyebabkan pertumbuhan ikan Bandeng menyusut dan hasil produksi menurun menyebabkan kerugian bagi para petani ikan. Faktor lain dari menurunnya hasil produksi ikan dapat diperkirakan dari keanekaragaman mikroorganisme di perairan tambak yang kecil.

Sebab produktivitas sebuah tambak sangat bergantung pada banyaknya keanekaragaman mikroorganisme salah satunya plankton sebagai pakan alami dan sebagai penentu kualitas suatu perairan [4]. Tujuan dari penelitian ini yaitu untuk mengidentifikasi, mengetahui perbedaan, mengetahui tingkat kenekargaman jenis plankton dan mengetahui kondisi faktor abiotik kolam. Oleh karena itu, perlu adanya penelitian lebih lanjut mengenai kualitas air dalam tambak sesuai Peraturan Menteri Kelautan dan Perikanan No. PER.01/MEN/2007 tentang Pengendalian Sistem Jaminan Mutu dan Keamanan Hasil Perikanan dapat menjadi penentu tingkat keanekaragaman mikroorganisme plankton serta identifikasinya di perairan tambak ikan Bandeng.

\section{Material dan Metode}

\section{Bahan dan Alat}

Bahan yang digunakan meliputi bahan yang digunakan untuk fiksasi plankton yaitu formalin $4 \%$ dan 3 ppm $\left(\mathrm{CuSO}_{4} \cdot 5 \mathrm{H}_{2} \mathrm{O}\right)$, aquades. Alat yang digunakan dalam penelitian ini meliputi alat untuk mengukur kualitas perairan, pengambilan sampel dan mengamati kelimpahan dan keanekaragaman plankton diantaranya: Refraktometer meter, $\mathrm{pH}$ meter, termometer air, lux meter, anemometer, DO meter, botol winkler $100 \mathrm{ml}$, ember, plankton net, Mikroskop digital Optilab, Haemocytometer, gelas penutup, pipet, kertas label, tissue, alat tulis, kamera, selotip, gunting, note book dan buku identifikasi Plankton milik Shirota [5].

\section{Metode}

Pengambilan plankton dalam air tambak sebagai bahan penelitian sebanyak 24 sampel dari 3 kolam yang terparasiti dan 1 kolam yang tidak terparasiti dengan metode Rancangan Acak Kelompok (RAK).

\section{Cara Kerja}

Pengambilan Sampel: Pengambilan sampel dari 4 kolam dilakukan dengan menggunakan plankton net berukuran no. 25 mesh durasi pengambilan tiap 90 menit sekali dalam 1 hari penuh, 1 kali saring untuk 1 sampel. Koleksi plankton dilakukan dengan menyaring $5 \mathrm{~L}$ air tambak dalam ember dengan plankton net dan menampungnya dalam botol winkler $100 \mathrm{ml}$. Sampel dalam botol winkler $100 \mathrm{ml}$ diawetkan dengan 4 tetes formalin $4 \%$ dan 5 tetes terusi 3 ppm $\left(\mathrm{CuSO}_{4} \cdot 5 \mathrm{H}_{2} \mathrm{O}\right)$ agar fitoplankton tetap berwarna hijau [6]. Setelah itu, botol ditutup rapat dan diberi label. Botol-botol tersebut dibawa ke laboratorium untuk diidentifikasi, di hitung cacah individu dan densitasnya.

Pengukuran Kualitas Perairan (Faktor Abiotik): Pengukuran yang dilakukan terhadap kualitas perairan meliouti suhu, angin, intensitas cahaya, total suspended solid (TSS), salinitas, $\mathrm{pH}$, dan derajat keasaman (DO). 
e-Jurnal Ilmiah BIOSAINTROPIS (BIOSCIENCE-TROPIC)

Volume 6/ No.: 1 / Halaman 89 - 95 / Agustus Tahun 2020

ISSN : 2460-9455 (e) - 2338-2805(p)

Identifikasi Plankton: Identifikasi plankton dilakukan di Laboratorium Halal Center Universitas Islam Malang menggunakan mikroskop digital Optilab. Langkah pertama yang dilakukan adalah dengan mengambil hasil fiksasi plankton dengan pipet dalam botol winkler $100 \mathrm{ml}$ lalu di teteskan ke Hemocytometer di tutup menggunakan gelas penutup kemudian diamati di mikroskop digital Optilab. Setelah itu dilakukan identifikasi plankton yang berpedoman referensi [5].

Analisis Data: Dari data yang telah didapatkan maka akan dianalisa untuk mengetahui indeks keanekaragaman dan kerapatan plankton.

1. Indeks Keanekaragaman (H')

Menurut Shannon dan Weinner [7], indeks keanekaragaman dapat dihitung dengan menggunakan rumus:

$$
H^{\prime}=-\sum_{t-1}^{s} \frac{n i}{\mathrm{~N}} \ln \frac{n i}{N}
$$

Keterangan:

H' = Indeks Keanekaragman Shannon;

ni $=$ Nilai penting suatu spesies;

$\mathrm{N}=$ Total nilai penting;

$\mathrm{s}=$ Jumlah spesies.

2. Kerapatan (Density)

Keterangan :

$$
n=a \times \frac{c}{L}
$$

$\mathrm{n}:$ densitas (kerapatan) plankton (idv/ml).

a : cacah individu plankton dalam $1 \mathrm{ml} \mathrm{sampel.}$

c : volume konsentrasi plankton dalam winkler $(100 \mathrm{ml})$.

L : volume plankton yang dicuplik (liter).

\section{Hasil dan Diskusi}

Jenis Plankton yang Terdapat dalam Kolam Pertumbuhan Ikan Bandeng: Dari pengambilan sampel dan pengamatan Fitoplankton di lapangan serta dilakukan identifikasi menurut The Plankton of South Vietnam, Fresh Water and Marine Plankton [5] ditemukan 118 spesies fitoplankton dan 45 spesies zooplankton masing-masing dengan 10 jumlah terbanyak (Tabel 1).

\begin{tabular}{|c|c|c|c|c|c|c|}
\hline \multirow[b]{2}{*}{ No. } & \multirow[b]{2}{*}{ Spesies } & \multicolumn{4}{|c|}{ Jenis Kolam } & \multirow[b]{2}{*}{ Jumlah } \\
\hline & & $\begin{array}{c}\text { Tidak } \\
\text { Terparasiti }\end{array}$ & Terparasiti 1 & Terparasiti 2 & Terparasiti 3 & \\
\hline 1. & $\begin{array}{l}\text { Chlorococcum } \\
\text { humicola }\end{array}$ & 19 & 8 & 1 & 25 & 53 \\
\hline 2. & Chlorella variegatus & 8 & 5 & 1 & 22 & 36 \\
\hline 3. & Nostoc sphaericum & 9 & 3 & 1 & 5 & 18 \\
\hline 4. & Protococcus viridis & 1 & 10 & 2 & 1 & 14 \\
\hline 5. & $\begin{array}{l}\text { Aphanocapsa } \\
\text { pulchra }\end{array}$ & 1 & 0 & 3 & 8 & 12 \\
\hline 6. & Bunilleria sicula & 3 & 1 & 0 & 8 & 12 \\
\hline 7. & Phacus lismorensis & 2 & 2 & 0 & 7 & 11 \\
\hline 8. & Navicula placentula & 2 & 4 & 1 & 3 & 10 \\
\hline 9. & $\begin{array}{l}\text { Euglena } \\
\text { pseudoviridis }\end{array}$ & 2 & 1 & 0 & 7 & 10 \\
\hline 10. & Surirella ovalis & 5 & 1 & 0 & 4 & 10 \\
\hline
\end{tabular}

Tabel 1. Fitoplankton dengan 10 Spesies Jumlah Sel Terbanyak 
e-Jurnal Ilmiah BIOSAINTROPIS (BIOSCIENCE-TROPIC)

Volume 6/ No.: 1 / Halaman 89 - 95 / Agustus Tahun 2020

ISSN : 2460-9455 (e) - 2338-2805(p)

Setelah dilakukan pengamatan dan identifikasi pada kolam pertumbuhan Ikan Bandeng ditemukan 10 spesies dengan jumlah terbesar dari 4 kolam. Jumlah sel terbesar yang didapat yaitu Chlorococcum humicola sebanyak 53 sel dan jumlah sel terkecil yang didapat yaitu Surirella ovalis sebanyak 10 sel.

Tabel 2. Zooplankton dengan 10 Spesies Jumlah Individu Terbanyak

\begin{tabular}{|c|c|c|c|c|c|c|}
\hline \multirow[b]{2}{*}{ No. } & \multirow[b]{2}{*}{ Spesies } & \multicolumn{4}{|c|}{ Jenis Kolam } & \multirow[b]{2}{*}{ Jumlah } \\
\hline & & $\begin{array}{c}\text { Tidak } \\
\text { Terparasiti }\end{array}$ & Terparasiti 1 & Terparasiti 2 & Terparasiti 3 & \\
\hline 1. & Stentor roeseli & 18 & 10 & 1 & 8 & 37 \\
\hline 2. & Stentor ignaeus & 16 & 2 & 0 & 0 & 18 \\
\hline 3. & Trichoplax adhaerens & 0 & 0 & 2 & 10 & 12 \\
\hline 4. & Amoeba guttula & 1 & 5 & 1 & 0 & 7 \\
\hline 5. & Metopus es & 5 & 2 & 0 & 0 & 7 \\
\hline 6. & $\begin{array}{l}\text { Trachellophylum } \\
\text { apiculatum }\end{array}$ & 0 & 3 & 0 & 3 & 6 \\
\hline 7. & $\begin{array}{l}\text { Centropyxis } \\
\text { constricta }\end{array}$ & 1 & 4 & 0 & 0 & 5 \\
\hline 8. & $\begin{array}{l}\text { Tintinnidium } \\
\text { fluviatile }\end{array}$ & 3 & 2 & 0 & 0 & 5 \\
\hline 9. & Cothurnia imberbis & 1 & 0 & 0 & 3 & 4 \\
\hline 10. & $\begin{array}{l}\text { Mesopodopsis } \\
\text { slabberi }\end{array}$ & 0 & 2 & 1 & 0 & 3 \\
\hline
\end{tabular}

Setelah dilakukan pengamatan dan identifikasi pada kolam pertumbuhan Ikan Bandeng ditemukan 10 spesies terbesar dari 4 kolam. Jumlah individu terbesar yang didapat yaitu spesies Stentor roeseli sebanyak 37 individu dan individu dengan jumlah terkecil yaitu spesies Mesopodopsis slabberi sebanyak 3 individu.

Perbedaan Jenis Plankton pada Kolam Ikan Bandeng yang Terparasiti dan Tidak Terparasiti: Dari Tabel diatas terdapat 5 jenis spesies Fitoplankton yang keberadaannya ditemukan pada 4 kolam, yatiu Chlorella variegatus, Chlorococcum humicola, Navicula cuspidata, Navicula placentula, Nostoc sphaericum, dan Protococcus viridis. Sedangkan jenis spesies lain banyak sekali perbedaan pada lokasi keberadaanya di masing-masing kolam. Dari tabel diatas terdapat hanya 1 jenis spesies Zooplankton yang keberadaannya ditemukan pada 4 kolam, yatiu Stentor roeseli. Sedangkan jenis spesies lain banyak sekali perbedaan pada lokasi keberadaanya di masing-masing kolam.

Tabel 3. Keberadaan Jenis Plankton di Kolam Ikan Bandeng yang Diteliti

\begin{tabular}{|c|c|c|c|c|c|}
\hline \multirow[b]{2}{*}{ No. } & \multirow[b]{2}{*}{ Spesies Fitoplankton } & \multicolumn{4}{|c|}{ Jenis Kolam } \\
\hline & & $\begin{array}{c}\text { Tidak } \\
\text { Terparasiti }\end{array}$ & $\begin{array}{c}\text { Terparasiti } \\
1\end{array}$ & $\begin{array}{c}\text { Terparasiti } \\
2\end{array}$ & $\begin{array}{c}\text { Terparsiti } \\
\mathbf{3}\end{array}$ \\
\hline 1. & Chlorella variegatus & + & + & + & + \\
\hline 2. & Chlorococcum humicola & + & + & + & + \\
\hline 3. & Navicula cuspidata & + & + & + & + \\
\hline 4. & Navicula placentula & + & + & + & + \\
\hline 5. & Nostoc sphaericum & + & + & + & + \\
\hline 6. & Protococcus viridis & + & + & + & + \\
\hline \multirow[b]{2}{*}{ No. } & \multirow[b]{2}{*}{ Spesies Zooplankton } & \multicolumn{4}{|c|}{ Jenis Kolam } \\
\hline & & $\begin{array}{c}\text { Tidak } \\
\text { Terparasiti }\end{array}$ & $\begin{array}{c}\text { Terparasiti } \\
1 \\
\end{array}$ & $\begin{array}{c}\text { Terparasiti } \\
2\end{array}$ & $\begin{array}{c}\text { Terparsiti } \\
\mathbf{3} \\
\end{array}$ \\
\hline 1. & Stentor roeseli & + & + & + & + \\
\hline
\end{tabular}

Keterangan + : Ada; - : Tidak Ada 
Tingkat Keanekaragaman Plankton dalam Kolam Pertumbuhan Ikan Bandeng (Chanos chanos Forsskal): Indeks keanekaragaman dikategorikan dalam beberapa tingkat seperti berikut:
$\mathrm{H}^{\prime}>3,0$
: Sangat Tinggi
H' $1,0-1,59$
: Sedang
H’ 1,6-2,99 : Tinggi
$H^{\prime}<1,0$
: Rendah

Berdasarkan grafik $\mathrm{H}^{\prime}$ di atas dari ke 4 kolam tersebut kolam Kontrol adalah kolam yang memiliki $H^{\prime}$ tertinggi yaitu 5,7, selanjutnya kolam 3 adalah kolam yang memiliki $H^{\prime}$ tertinggi kedua setelah kolam kontrol yaitu $\mathrm{H}^{\prime}=5,6$, kemudian kolam 1 memiliki $\mathrm{H}^{\prime}$ yang cukup tinggi sebesar 5,2, sedangkan kolam 2 adalah Kolam yang memiliki H' paling rendah sebesar 5,0.

\section{Tingkat Keanekaragaman}

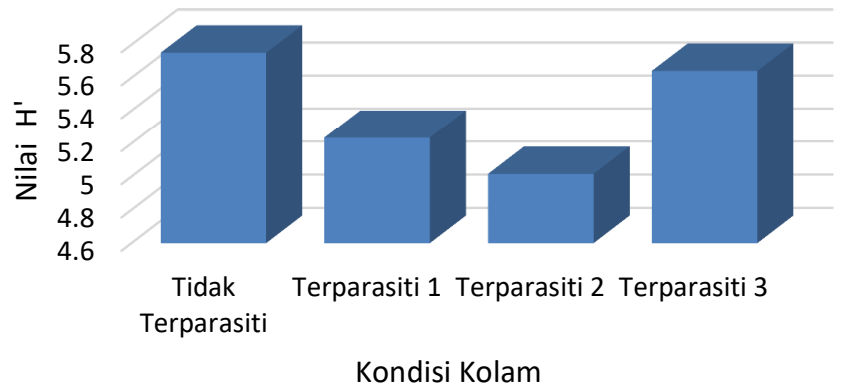

\section{Gambar 1. Nilai Indeks Keanekaragaman di Berbagai Kondisi Kolam}

Kondisi Faktor Abiotik yang Ada Di Kolam Pertumbuhan Ikan Bandeng (Chanos chanos Forsskal): Berdasarkan hasil rerata pengukuran faktor abiotik dengan beberapa parameter ukur yang telah dilakukan, kemudian dibandingkan dengan Standar Kualitas Air untuk Budidaya Tambak. Melalui (Tabel 4) dapat dilihat bahwa hasil rerata dari Suhu kolam yaitu $26,1^{\circ} \mathrm{C}-26,3^{\circ} \mathrm{C}$ dengan standar kualitas $26-32{ }^{\circ} \mathrm{C}$. Salinitas kolam yaitu $25 \mathrm{o} / \mathrm{oo}$ dengan standar kualitas sebesar $15-30 \mathrm{o} / \mathrm{oo}$. Derajat keasaman kolam yaitu terparasiti 1 7,4, terparasiti 2 7,5, terparasiti 38,1 dan kolam tidak terparasiti 8,5 dengan standar kualitas 7,5-8,7. Jika dibandingkan dengan Standar Kualitas Air untuk Budidaya Tambak 3 kolam diantaranya masih sesuai hanya kolam terparasiti 1 yang dibawah standar.

Tabel 4. Hasil Rerata Faktor Abiotik pada Kolam Air Payau yang Dibandingkan dengan Standar Kualitas Air untuk Budidaya Tambak

\begin{tabular}{|c|c|c|c|c|c|c|c|}
\hline & \multicolumn{7}{|c|}{ Parameter } \\
\hline & \multicolumn{4}{|c|}{ Fisika } & \multicolumn{3}{|c|}{ Kimia } \\
\hline & $\begin{array}{l}\text { Suhu } \\
\left({ }^{\circ} \mathrm{C}\right)\end{array}$ & $\begin{array}{c}\text { Angin } \\
(\mathrm{m} / \mathrm{s})\end{array}$ & $\begin{array}{c}\text { Cahaya } \\
\text { (cd) }\end{array}$ & $\begin{array}{l}\text { TSS } \\
(\mathrm{g} / \mathrm{L})\end{array}$ & $\begin{array}{c}\text { Salinitas } \\
\text { (o/oo) }\end{array}$ & pH & $\begin{array}{c}\text { DO } \\
\text { (ppm) }\end{array}$ \\
\hline $\begin{array}{l}\text { Standar } \\
\text { Kualitas }\end{array}$ & $26-32$ & - & - & - & $15-30$ & $7,5-8,7$ & $3-10$ \\
\hline Terparasiti 1 & 26,1 & 31,3 & 105,7 & 2,3 & 25 & $* 7,4$ & 8,1 \\
\hline Terparasiti 2 & 26,3 & 31,3 & 105,7 & 2,3 & 25 & 7,5 & 8,9 \\
\hline Terparasiti 3 & 26,1 & 31,3 & 105,7 & 2,4 & 25 & 8,1 & 7,1 \\
\hline $\begin{array}{c}\text { Tidak } \\
\text { Terparasiti }\end{array}$ & 26,3 & 31,3 & 105,7 & 1,5 & 25 & 8,5 & 8,2 \\
\hline
\end{tabular}

Keterangan: * = dibawah standar 
Kondisi $\mathrm{pH}$ untuk kesuburan hidup jasad renik sangat berpengaruh dalam rantai makanan ekosistem perairan. Tambak menjadi tidak subur jika $\mathrm{pH}$ air terlalu rendah atau terlalu tinggi sehingga perombakan bahan organik menjadi garam mineral dalam perairan terhambat [8]. Nilai DO terendah dari semua kolam yaiu kolam terparasiti 3 sebesar 7,1 ppm dengan standar kualitas air DO sebesar 310 ppm. Pengaruh rendahnya DO berdampak pada keberlangsungan hidup ikan dalam memperoleh oksigen terlarut untuk bernafas dan bertahan hidup. Rendahnya oksigen terlarut menunjukkan bahwa kolam terparasiti 3 memiliki kondisi perairan yang cukup buruk untuk ikan, didukung oleh lokasi kolam terparasiti 3 yang cukup banyak ditemukan sampah dibagian pinggir kolam, di dasar maupun mengambang di permukaan. Lokasi kolam terparasiti 3 juga dekat dengan pemukiman warga, dapat diperkirakan kolam terparasiti 3 perairannya telah tercemar oleh limbah rumah tangga sehingga menyebabkan kadar DO berada di bawah standar. Menurut Nybakken [9] penyebab terjadinya penurunan kadar oksigen terlarut (DO) adalah karena adanya pelepasan oksigen ke udara, aliran air tanah ke dalam perairan, keberadaan zat besi, reduksi gas lain dalam air, respirasi biota dan dekomposisi bahan organik. Dampak yang ditimbulkan dalam penurunan kadar DO jumlah sedang adalah menururnnya kegiatan fisiologis biota air sehingga terjadi penurun nafsu makan, pertumbuhan dan kecepatan berenang ikan [10]. Menurunnya nafsu makan ikan selain karena penurunan kadar DO yaitu karena adanya cacing parasit Nematoda yang di temukan pada usus ikan Bandeng. Penurunan nafsu makan yang terjadi pada ikan menyebabkan pertumbuhan pada fitoplankton dan zooplankton berkembang sangat cepat, sehingga pertumbuhan ikan pun terhambat dan hasil panen ikan menurun.

\section{Kesimpulan}

Berdasarkan hasil pengamatan dan identifikasi spesies Fitoplankton dan Zooplankton pada Kolam Pertumbuhan Ikan Bandeng, spesies Fitoplankton dengan densitas tertinggi pada spesies Chlorococcum humicola sebanyak 53 sel dan spesies Zooplankton dengan densitas tertinggi pada spesies Stentor roeseli sebanyak 37 individu. Ditemukan 5 spesies Fitoplankton dan 1 spesies Zooplankton yang keberadaannya ada di semua kolam. Kolam tidak terparasiti merupakan kolam yang memiliki nilai tingkat keanekaragaman plankton tertinggi $(5,7)$, daripada kolam terparasiti 2 $(5,0)$. Kondisi faktor abiotik $(\mathrm{pH})$ pada semua kolam masih sesuai standar kualitas air untuk budidaya tambak.

\section{Daftar Pustaka}

[1] Suprapto. 2011. Metoda Analisis Parameter Mutu Air untuk Pembudidaya Udang. Bagian Pengembangan Teknologi Budidaya Shrimp Club Indonesia. Pacitan. hal: 35-37.

[2] Faza, M.F. 2012. Struktur Komunitas Plankton di Sungai Pesanggrahan dari Bagian Hulu Hingga Bagian Hilir. Skripsi. Fakultas Matematika dan Ilmu Pengetahuan Alam Departemen Biologi. Universitas Indonesia. Hal 2.

[3] Rohman, F. 2018. Kajian Faktor Lingkungan Abiotik pada Kolam Ikan Bandeng (Chanos chanos Forsskal) di Desa Balongpanggang (Suspected Parasites). Skripsi. Fakultas Matematika dan Ilmu Pengetahuan Alam. Universitas Islam Malang. Hal 3-4.

[4] Adhikari, S. 2003. Fertiliziation, Soil And Water Quality Management In Small Scale Ponds. Aquaculture Asia. Vol VIII No.4: 6-8

[5] Shirota, A. 1966. The Plankton of South Vietnam: Freshwater and Marine Plankton. Over Tech Coop Agent. Japan

[6] Mukharomah, E., Suheryanto, Elyza, F., dan Muli, R. 2012. Keterkaitan Komunitas Fitoplankton Dengan Kualitas Air Di Danau Sky Air Jakabaring Palembang. Journal of Biosciences Vol. 4 No. 2 Agustus 2018 ISSN 2460-6804 
e-Jurnal Ilmiah BIOSAINTROPIS (BIOSCIENCE-TROPIC)

Volume 6/ No.: 1 / Halaman 89 - 95 / Agustus Tahun 2020

ISSN : 2460-9455 (e) - 2338-2805(p)

[7] Shannon, C. E., dan Wiener, W. 1949. The Mathematical Theory of Communication. University Illinois Press IL. Urbana, US

[8] Santosa, M.B dan Wiharyanto, D. 2013. Studi Kualitas Air Di Lingkungan Perairan Tambak Adopsi Better Management Practices (BMP) Pada Siklus Budidaya I, Kelurahan Karang Anyar Pantai Kota Tarakan Propinsi Kalimantan Utara. Jurnal Harpodon Borneo Vol.6. No.1. ISSN : 2087-121X

[9] Nybakken, J.W. 1988. Marine Biology and Ecology Approach. Gramedia. Jakarta. 459 p.

[10] Simanjuntak, M. 2009. Hubungan Faktor Lingkungan Kimia, Fisika Terhadap Distribusi Plankton di Perairan Belitung Timur, Bangka Belitung. Jurnal Perikanan (J. Fish. Sci.) XI (1): $31-45$. 